\title{
THE CONCEPTUAL ORIENTATION OF THE SYSTEM OF REGULATION OF INDUSTRIAL DEVELOPMENT
}

\author{
Yuriy Melnyk' ${ }^{1}$, Vyacheslav Truba²
}

\begin{abstract}
The industrial sector is the most important segment of the macroeconomic environment of the country, the performance of which depends on its functioning and development in the global economic environment. The development of industry in the national macroeconomic environment is possible at the expense of an effective regulatory system, which should have modern instrumental support that corresponds to modern trends in the development of global economic systems. The article is based on the theoretical and methodological foundations of the formation of a system for regulating the development of industry and defining its conceptual benchmarks in the conditions of transformation changes in the economy. Methodology. Legislative and normative documents, materials of periodicals, statistical data, and Internet resources were the information base of the study. The paper uses general scientific and special methods: monographic examination, generalization, systematization, economicstatistical analysis, and modelling. This allowed investigating the current state and possibilities of regulating the development of industry in different models of the regulatory system and the forms of its implementation, substantiating the conceptual foundations and directions of the transformation of the system of regulation of the development of the domestic industrial sector and criteria for evaluating its effectiveness. Results. It is proved that the process of regulating the development of industry in the national economy should be considered from the point of view of a systemic approach in the macroeconomic environment, where the basic elements of a defined system are the purpose, strategic guidelines and objectives, principles and limitations, regulatory functions, institutional actors that influence on industry and its structural units with the help of well-grounded tools. The expediency of assessing the system of regulation of industrial development based on the criteria of rationality, regulation, management, and efficiency is proved, and models of the corresponding analytical indicators are proposed. It is proved that the formation of the most perspective and effective mechanism of regulating the development of the industry is to find the optimal combination of vectors of rationality and efficiency in the implementation of all large-scale transformations in the system of regulation in the national macroeconomic environment. The alternative development options in the domestic industrial sector and the relevant conceptual guidelines for the regulation of the development of industry in the national macroeconomic environment are determined. Practical meaning. The introduction of these results in order to change the system of regulation of industrial development will contribute to ensuring the role of the industrial sector as the main driver of innovation and investment development of the country's economy. Value/originality. The author's definition of the process of regulating the development of industry from the standpoint of the system approach, proposed methodological approaches to the assessment of the effectiveness of the development regulation system according to criteria and indicators of rationality and manageability, is aimed at the further formation of system measures to create favourable conditions for the development of industry in the national macroeconomic environment.
\end{abstract}

Key words: industry, development, regulation, system, efficiency, national macroeconomic environment.

JEL Classification: E20, E60, L50, L60, O10, O38

\section{Introduction}

The industrial sector is the most important segment of the macroeconomic environment of the country, which creates a national product to meet the needs of society in the domestic and foreign

Corresponding author:

${ }^{1}$ Odesa National Academy of Food Technologies, Ukraine.

E-mail:9701080@ukr.net

${ }^{2}$ Odesa I.I. Mechnikov National University, Ukraine.

E-mail: truba-v@ukr.net markets. The current period of development of the industrial segment of the national economy can be characterized as unstable, as it is associated with significant risk factors, constant changes, losses, and crises. 
Industry in the structure of the national economy creates a gross domestic product over $32 \%$, gross value added $-21 \%$, the number of jobs $-20 \%$. The industrial sector of the national economy includes almost 42 thousand subjects of different forms of ownership.

Industry is the aggregate of mining enterprises engaged in the extraction of raw materials and materials for the purpose of their further processing, and enterprises of the processing industry, raw materials, materials, products obtained in industry or produced in agriculture, and the production of tools for others sectors of the economy, and for the needs of the industry itself (Strategy for the development of the industrial complex of Ukraine for the period until 2025, 2018). The highest share in the structure of the domestic industry is: extractive industry and quarry development; processing industry; power engineering.

The system of its functioning depends on the performance of the industrial segment of the national macroeconomic environment. The structure of the industry, indices and growth rates, management results and business activity of the industry formulate analytical tools that show quantitative and qualitative characteristics of the development of the national macroeconomic environment of the country.

The development of industry should be understood structural changes in the industry to form effective resource proportions of industrial production and qualitative improvement of the components of industrial progress and industrial potential in the national macroeconomic environment.

Macroeconomic development processes of the industry should be guided by ensuring a stable and balanced growth of industrial production, provided that the functional full-fledged extended reproduction is restored, which involves not only an increase in the output of industrial products but also the ability of the subjects of the industry to produce innovationinvestment orientation in the macroeconomic environment of the country (Stigler, 1971).

The development of industry in the national macroeconomic environment is possible due to an effective regulatory system, which should have modern tooling that meets modern trends in the development of economic systems. It updates theoretical and applied research in this field.

\section{Theoretical foundations of the industrial development regulation system}

Regulating the development of industry includes regulatory, organizational, production, innovationinvestment, and socio-economic aspects. In the opinion of the authors (National Economy, 2011), the purpose of regulating the development of industry in the national environment is to create a modern, integrated industrial complex in the world capable of solving the main tasks of social and economic development and consolidating Ukraine as a high-tech state in the conditions of integration and globalization. This involves realizing the tasks of activating the transformational-institutional and innovation-investment activity of the industry with a positive impact on its volume and structure of production, accelerating the integration of the industrial complex into world production.

The strategic aim of regulating the development of industry in a transformational environment and the aggressive policy of the external environment is ensuring sustainable economic growth, raising socioeconomic standards, and ensuring the national security of Ukraine. Taking into account certain aspects, the study of theoretical and methodological issues of regulation of the development of the industry of the national economy is an urgent and necessary task.

The questions of the regulation of the development of the national economy and its structural elements are devoted to the works of Ukrainian and foreign scientists: O. Amoshi, B. Andrushkiv, H. Amstroung, Y. Bajala, B. Birenberaga, S. Vaskova, O. Veklych, O. Vovchak, O. Galytsova, L. Didkovskaya, P. Druckera, V. Heyetsa, M. Kovalenko, A. Epiphanova, E. Libanova, G. Grigoryeva, A. Kruglyak, L. Shwaika, A. Maddisona, V. Margasova, V. Muntiana, I. Myshusyuka, A. Nikiforova, I. Rosupatenko, Yu. Safonov, E. Maslennikova, J. Stiglitsa, N. Nizhnikova, M. Tymchuka, R. Fathundinova, K. Shaposhnikova, R. Hailbrona, S. Ilyppovoyi, and others. Some theoretical and methodological aspects of the foundation of the system of regulation of transformational processes in the national macroeconomic environment are reflected in the works: V. Apopia, M. Barney, B. Burkinsky, M. Doleshny, A. Galchinsky, O. Kuzmin, E. Kuznetsov, O. Kovalenko, M. Merkulov, B. Mizyuk, B. Semak, O. Poberezhets, and others. The scientific works of the listed researchers confirm that regulation is an indirect effect of the subject of regulation of objects on regulation in order to influence their condition, behaviour or spatial and temporal movement in the macroeconomic environment (Figure 1).

An important requirement of this system is the possibility of the independent existence of objects regulation from the regulatory system to the actual process of regulation. The control system consists of three levels. Adoption of strategic decisions on the operation of industry and development of market structure is carried out at the first level; development and adoption of executive decisions on the current and mid-term functioning of industry and its structural segment elements - on the second; the development of regulatory signals and a command for a regulated system - at the third level. The adjustable system is the implementation of regulatory signals and commands on regulatory objects, including the perception of the transformation of regulatory decisions and commands. 


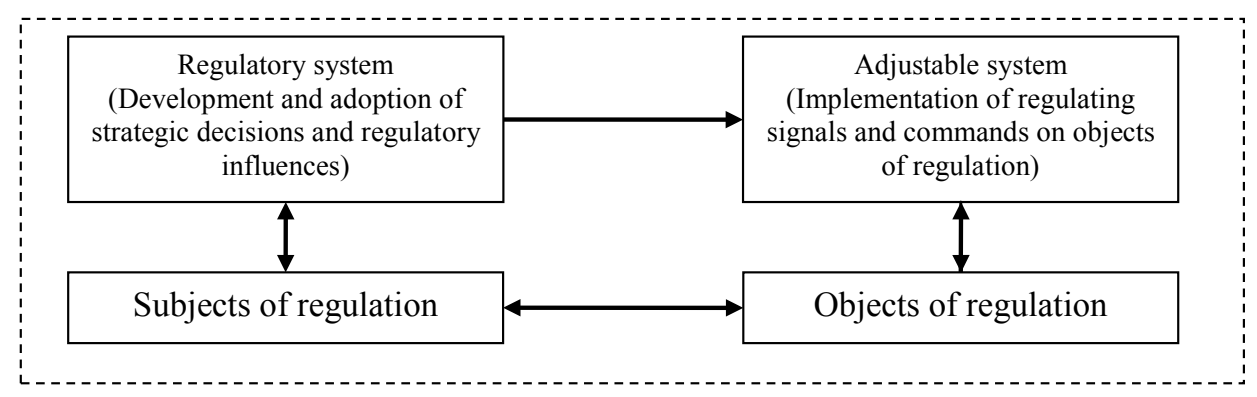

Figure 1. Typical scheme of the industrial regulation system

Regulation of industry in the national macroeconomic environment is a system of appropriate measures that provide supportive, compensatory, and regulatory influential industrial production in order to create optimal conditions for the effective functioning of the industry.

Regulation of industry has the following meaning: a) is identified with institutional interference in industrial production; b) administrative legal regulation of economic activity in the industry.

Regulation (from the Latin regulare), in the broadest sense, means subordination to a certain principle order.

Thus, state regulation of industry - a complex of targeted measures of state institutions, which are aimed at directing the behaviour of subjects of the industrial sector in the direction necessary for solving the tasks of the system of state regulation of the national economy.

Effectiveness of state regulation - as a combination of the effects of management decisions at the level of central and municipal authorities that implement regulatory policy, can be considered the final result of meeting the needs (requirements) of the society, taking into account legitimacy and legality, in the conditions of resource constraints, which is being implemented in order to achieve strategic goals of public administration. The effectiveness of state regulation of industrial production in Ukraine is the result of solving problems and making decisions on further development of industries in all spheres of activity within the framework of the current legislation, powers and competence of state authorities at local, regional, and national levels, in the conditions of resource constraints, uncertainty and conflict of economic the interests that are being achieved in the process of implementing strategic goals (Wenzha, 2015).

\section{Models of the system of regulating the development of industry and tools for their evaluation}

The Ministry of Economic Development and Trade of Ukraine, with the aim of regulating the development of industry in the national macroeconomic environment, developed the Strategy for the development of the industrial complex Ukraine for the period up to 2025 . Ensuring the formation of a strategic state industrial policy is a priority factor in restoring the role of the country's industry in stimulating macroeconomic growth and enhancing the competitiveness of the national economy in the international global environment.

It should be noted that the insufficient consideration of competition requirements in the global international markets for industrial products, current trends in the diversification of production in the industrial sector, export potential, and lack of resource support slow down the processes of structural transformation in the industrial sector of the country's national macroeconomic environment.

Current target indicators, strategic priorities, and specific tools for industrial development in the national macroeconomic environment require a systematic program approach that will ensure socio-economic growth and development in the industrial sector of the country.

According to the analytical data of the State Statistics Service of Ukraine (Table 1), in 2018, compared to 2013 , the index of industrial output amounted to $101.6 \%$ and $95.7 \%$, and shows positive dynamics in the last two years, indicating a gradual recovery of the industry. In the mining industry and the development of quarries, in 2018 the index of industrial output amounted to 102.4 , in the processing industry - $101.1 \%$, in the energy segment $-102.8 \%$.

Indices of industrial output by main industrial groups are presented in Table 2. Indicators of January-February 2019, unfortunately, show a negative sign, therefore, it is necessary to focus on the reasons that influenced the reduction of these indicators.

It should be remembered that industry is a systemforming component in the national macroeconomic environment, which forms the added value, resource support, satisfies the needs of society in the goods needed for existence.

From the experience of industrialized countries, it is known that industrial policy should be an integral part of the state policy of development of the national economy.

The system of regulation of the development of industry country relies on the following program documents:

- The Law of Ukraine dated July 1, 2010, No. 2411-VI

"On the Principles of Internal and Foreign Policy"; 
Table 1

Indices of industrial production by main types of activity

\begin{tabular}{|c|c|c|c|c|c|c|}
\hline \multirow{2}{*}{ Industrial sector } & \multicolumn{6}{|c|}{ Years } \\
\hline & 2013 & 2014 & 2015 & 2016 & 2017 & 2018 \\
\hline Industry & 95,7 & 89,9 & 87,0 & 102,8 & 100,4 & 101,6 \\
\hline Mining and processing industry & 95,2 & 89,3 & 86,9 & 102,9 & 101,6 & 101,5 \\
\hline Mining and quarrying & 100,8 & 86,3 & 85,8 & 99,8 & 94,3 & 102,4 \\
\hline mining of stone and brown coal & 97,6 & 69,5 & 61,9 & 104,8 & 83,7 & 104 \\
\hline extraction of crude oil and natural gas & 96,3 & 98,3 & 95,0 & 97,4 & 100,2 & 103,1 \\
\hline extraction of metal ores & 104,6 & 93,4 & 95,0 & 97,9 & 93,7 & 102,5 \\
\hline Manufacturing industry & 92,7 & 90,7 & 87,4 & 104,3 & 104,8 & 101,1 \\
\hline Manufacture of food products, drinks and tobacco products & 95,0 & 102,5 & 89,3 & 104,4 & 102,9 & 98,5 \\
\hline $\begin{array}{l}\text { Textile production, clothing, leather, leather goods } \\
\text { and other materials }\end{array}$ & 94,1 & 98,6 & 92,0 & 102,2 & 107,2 & 96,8 \\
\hline $\begin{array}{l}\text { Manufacture of wood products, paper production and } \\
\text { printing activities }\end{array}$ & 102,7 & 96,0 & 88,9 & 102,0 & 105,8 & 102,5 \\
\hline Production of coke and refined products & 89,2 & 78,7 & 80,9 & 108,7 & 85,2 & 103,5 \\
\hline Production of chemicals and chemical products & 80,7 & 85,8 & 84,8 & 101,1 & 118,4 & 117,4 \\
\hline $\begin{array}{l}\text { Manufacture of basic pharmaceutical products } \\
\text { and pharmaceuticals }\end{array}$ & 111,8 & 101,9 & 92,4 & 104,4 & 106,9 & 101,1 \\
\hline $\begin{array}{l}\text { Manufacture of rubber and plastic products, other non- } \\
\text { metallic mineral products }\end{array}$ & 97,4 & 91,2 & 92,8 & 108,5 & 108,2 & 99,5 \\
\hline $\begin{array}{l}\text { Metallurgical production, production of finished metal } \\
\text { products, except machinery and equipment }\end{array}$ & 94,7 & 85,5 & 83,9 & 106,8 & 100,2 & 100,6 \\
\hline $\begin{array}{l}\text { Machine-building, except for repair and installation of } \\
\text { machinery and equipment }\end{array}$ & 86,4 & 79,4 & 85,9 & 102,0 & 107,9 & 101,6 \\
\hline production of computers, electronic and optical products & 86,0 & 77,9 & 71,3 & 124,2 & 109,2 & 99,7 \\
\hline production of elerical equipment & 91,1 & 100,9 & 89,8 & 100,9 & 97,5 & 82,5 \\
\hline $\begin{array}{l}\text { manufacture of machinery and equipment not attributed } \\
\text { to other groups }\end{array}$ & 93,5 & 88,7 & 87,5 & 102,3 & 106,6 & 103,3 \\
\hline $\begin{array}{l}\text { production of motor vehicles, trailers and semi-trailers } \\
\text { and other vehicles }\end{array}$ & 79,8 & 64,3 & 85,0 & 98,4 & 115,5 & 109,8 \\
\hline $\begin{array}{l}\text { Production of furniture, other products; repair and } \\
\text { installation of machinery and equipment }\end{array}$ & 90,9 & 93,0 & 84,5 & 101,3 & 111,1 & 105,6 \\
\hline Supply of electricity, gas, steam and air conditioning & 98,9 & 93,4 & 88,0 & 102,5 & 93,5 & 102,8 \\
\hline
\end{tabular}

Table 2

Indices of industrial production by main industrial groups

\begin{tabular}{|c|c|c|c|c|c|}
\hline \multirow{2}{*}{ Indexes } & \multicolumn{5}{|c|}{ Years } \\
\hline & 2014 & 2015 & 2016 & 2017 & 2018 \\
\hline Industry & 89,9 & 87,0 & 102,8 & 100,4 & 101,6 \\
\hline Intermediate consumption goods & 91,6 & 90,6 & 102,7 & 100,2 & 100,6 \\
\hline Investment goods & 79,7 & 85,3 & 101,7 & 110,6 & 106,3 \\
\hline Consumer goods of short-term use & 101,7 & 89,0 & 104,4 & 104,0 & 99,0 \\
\hline Consumer goods of durable use & 88,7 & 80,8 & 99,7 & 113,9 & 100,2 \\
\hline Energy & 85,5 & 81,8 & 102,4 & 92,3 & 103,2 \\
\hline
\end{tabular}

- The Law of Ukraine as of 19.06.2003 № 964-IV

"On the Fundamentals of National Security of Ukraine"; - The Decree of the President of Ukraine "On the Strategy of Sustainable Development 'Ukraine-2020”' (On the Strategy of Sustainable Development 'Ukraine 2020”, 2013);

- Order of the Cabinet of Ministers of Ukraine dated April 3, 2017, No. 275-p "On Approval of the MediumTerm Plan for Priority Actions of the Government by 2020”;
- National Report 2017 "Sustainable Development Goals: Ukraine”.

During all years of our country's independence, a large number of documents were developed and put into operation, which, however, were, unfortunately, only declarative.

In the opinion of the authors of the study, in the transformational conditions, the basic condition for the regulation of the development of the industry is to increase the rationality of the regulatory model of 
regulation, mainly in future periods of its functioning in the macroeconomic environment.

Typical regulatory model of regulation: the mission of the industrial sector; a system of regulation and restrictions of the environment; composition, scale, and quality of resource support; the algorithm for regulation and management of available resources.

The main mission of the rational regulatory model of regulation in the industry is the formulation of goals, principles, priority tasks, functions of processes regulation, as well as ways to solve them effectively, with the proposed regulatory model of methods and tools of the regulatory system.

Corresponding failures in the system of regulation of industrial development under unconditional compliance with the normative model are allowed only in the event of errors in the stages of planning or construction. It is offered the degree of rationality of the regulatory system to determine the indicator of its rationality:

$$
I r=\frac{R s}{R n}
$$

where $R s$ - the results of the profile industry in the standard model regulation with the use of optimal methods' regulation;

$R n$ - the results of the profile of the industry in the normative model of regulation.

The proposed indicator may be a criterion for assessing the value of unused reserves in industry. The greater the value of the indicator $I r$, the more urgent problem issues and measures for its rationalization, that is, improvement.

Significantly problematic is the definition of a standard model of regulation and the results obtained in its application. It should be noted that this is rather conditional concept, which is based on theoretical and methodological developments of the construction of the most promising and recognizable measure of ideal but practically inaccessible system regulation, the very approximation to which can already promise the industry a number of tangible benefits and benefits in the macroeconomic environment, to the generalized experience of functioning and the development of industry in industrially developed countries with an evolutionary and well-adjusted environment.

In assessing regulatory models of regulation and its segmental components, provide a synergistic effect of modern and future system regulation. The industry is conditionally allowed assuming that all the requirements of comparable models are met, but in reality, these requirements are not always met in the conditions of transformation.

Thus, another criterion and, at the same, time condition for the development of industry, including the regulatory model of regulation is its performance or practical application, the basic characteristic of which is the category of regulation.
If the rationality of the regulatory system is evaluated by the ability to develop and adopt a set of effective regulatory decisions, then the settlement is determined by the completeness and accuracy of the implementation of any regulatory decisions, regardless of the consequences of the industry.

The degree of controllability of the industrial development regulation system can be assessed as follows:

$$
K r=\frac{R e}{R r}
$$

where $K r$ - conversion coefficient;

$R e-$ Regulation of the regulatory model, provided all the parameters of the normative model and the resulting set of decisions, regulating signals or commands formed on its basis;

$R r$ - Regulation result for a real model, taking into account deviations from the normative model for all levels, tasks, processes, and other parameters.

A large number of scientists and practitioners consider the reasons for the rejection of the real model of relative communication with the imperfection of the latter. Under present conditions, the study of objective reasons deviation from the real model from the normative serves as a starting point for constant adjustment and improvement of the regulatory model of regulation in a legitimate way in the macroeconomic environment of the country.

European vector of development of the national macroeconomic environment requires a critical revision of legal and socio-economic regulations regulation in order to achieve their dynamic equilibrium, balancing the level of development in the industry of productive forces with industrial relations.

It is known that correcting the imperfection of laws imperfection of their implementation in a priori is impossible, because the loss of respect to any form of law and order and it is difficult to find objective or practically justified parameters of utility deviations from the officially legal principles of operation, since the benefit for the initiators of such unplanned deviations does not always turn around its consequences for the utility of the regulatory system in the macroeconomic environment. In this regard, any deviation from the regulatory model must include the costs of controllability of the regulatory system in the macroeconomic environment. The result of unplanned deviations of the real model from the regulatory is not only a reduction in the overall or systemic effect, as well as the creation of an informal regulatory structure in the macroeconomic environment. The informal structure of regulation is based on intuition, national traditions, subjective experience, individual knowledge, customs, forecasts, etc.

The basic reasons for the formation of an informal structure regulation: a) sufficient uncertainty of the regulatory model of regulation in non-standard 
situations; b) unsystematic discrepancy of the conservative normative model, more dynamic object regulation in the conditions of its growing complexity in changing conditions.

It should also be noted that the regulatory legal framework allows either a sufficiently significant degree of uncertainty or lack of information about the processes and phenomena that are important from the decisionmaking in the activities of subjects of the industrial industry of the national economy.

For example, the current classifier of industrial products, standards or certificates in many cases does not reflect all the necessary for regulation or management characteristics and parameters.

In such cases, subjective practical experience, intuition, knowledge, etc. complement the official information that provides informal influence on the nature of regulation of managerial decisions in the industrial sector, and in some cases, and correct errors in the regulatory model of regulation in the macroeconomic environment.

The main reasons for the deviations in the normative model are:

- Weakening regulatory influence, including positive and negative regulatory incentives, caused by the weakening of the control function, change socioeconomic settings, etc.;

- Change of political conditions that affect the regulatory system in the national macroeconomic environment;

- Change of socio-economic conditions and components of the system of regulation - criteria, parameters, a system of restrictions, etc.;

- Aggressive behaviour of the external environment, temporary occupation of the national territory and military actions, which objectively requires the change of objectives, principles, functions, and tasks of regulation;

- The emergence of a national macroeconomic environment organized by the shadow and even criminal structures that replace the system of regulatory regulation.

- The informal structure can be divided into two aspects:

- Part of a positive informal structure, which is subject to formalization, structuring, transpose ability, objectification, and legalization, followed by the introduction of a revised regulatory model of regulation; - Part of the negative informal structure, which is to be eliminated, as a negative obstacle in regulating the system, which reduces its efficiency in the macroeconomic environment.

Thus, the convergence of normative and real models regulation in the macroeconomic environment is achieved through their counter-correction and development, which provides increased efficiency of the regulation system. The convergence of normative and real models of regulation in the macroeconomic environment by reducing to an objectively necessary minimum of the informal structure is achieved as an improvement of the self-standard model by formalizing and legalizing the informal structure, and by improving the systems of regulatory influences through positive or negative incentives in the macroeconomic the environment of the country.

\section{Forms of implementation of the regulation of development in industry: preconditions and guidelines for implementation}

The implementation of regulation of the development of industry in the national economy should be carried out by means of appropriate forms that are reasonably systematized according to certain features, parameters, filled with separate tools of strategic influence and represent a general direction of the influence of subjects on the corresponding objects of regulation in the industrial sector of the national macroeconomic environment.

The process of regulating the development of industry in the national economy in the form of implementation has the following types:

- Priory regulation of the development of industry implemented in the form of targeted programming and designed to address the strategic objectives of the industry (growth of industrial production, improvement of productive forces, the use of innovations, etc.);

- Pastoral regulation of industrial development is implemented at the expense of various measures and tools of market-oriented nature and is intended primarily to maintain the balance of industrial production in the macroeconomic environment;

- Combined regulation of industrial development is implemented at the expense of certain socio-economic programs aimed at maintaining the balance of growth in economic performance in the industrial sector of the national economy.

It must be remembered that it is not necessary to reduce the manageability of a holistic system before the actual implementation of decisions of the management systems of different levels of the hierarchy of integral regulation systems in the macroeconomic environment. Thus, for example, the decision of state institutions in the form of codes, laws, decrees, regulations, orders, plans, forecasts, programs, tasks, etc., which are systemwide guidelines on the scale and strength of their influence, the legal competence of their sources, socioeconomic consequences, etc., cannot and do not have to specify the level of signals and commands in the system of regulating the development of industry, to require from them unconditionally executed.

Institutional regulation of the development of industry, even at the widest possible limits, substantiation, scale, and radical forms of rational and even optimal management in the industrial sector 
should provide a high degree of uncertainty, that is, limitation of content, tasks, and requirements.

The application of certain forms of regulation of the development of industry in the national economy depends on the conditions of the functioning of the national macroeconomic environment, the set strategic objectives, and the international situation.

Basic regulation of industrial development in the national economy:

- indicative planning of the growth of economic results in the industrial sector;

- forecasting the development of the domestic and external market of industrial products;

- realization of integrated programs of industrial production;

- state institutional support industrial production.

An important feature of the development of subjects of the industrial industry and the regulatory system is their ability to correctly identify and evaluate the effects of decisions taken and implemented (codes, laws, decrees, regulations, orders, plans, forecasts, programs, tasks, etc.), as well as the principles established on their basis of functioning in the national macroeconomic environment, with the help of reliable indicators and feedback with the realms of market environment development. Effective market mechanism of selfregulation should ensure the development of the industrial sector of the national economy.

Rationality and efficiency of the system of regulation of industry development can have both the same and opposite vectors direction in relation to the total component of these vector effectiveness of the system regulation in the national macroeconomic environment.

For example, increasing the degree of rationality of the system of regulation of industrial development by converting the normative model of regulation to its optimal option can simultaneously improve the efficiency of the regulatory system in the national macroeconomic environment.

This can happen, firstly, if you direct a part of the systemic effect from optimizing the regulatory process to stimulate industrial activity, and secondly - because of the greater degree of complexity of the regulatory system of the facility and the correct selection of the necessary regulatory influences - incentives and the creation of a complex administrative, organizational, economic, and social preconditions, which in turn increases the degree of efficiency of the system of regulation in the national macroeconomic environment.

In many cases, the rationality of the regulatory system comes into conflict with its ability to work in a macroeconomic environment. The historical process of the development of the regulatory system shows that the implementation of independent targeted programs reforming the system in relation to improving the parameters of rationality and workability can only be to a certain limit, which the resulting indicator of the efficiency of the system of regulation of industrial development begins rather sharply decrease.

Since rationality in the industrial sector is more closely related to the objective properties and requirements of the national economy and society, and efficiency to the basic essential characteristics of commoditymoney relations in the market environment, then the formation of the most promising and effective mechanism for regulating the development of industry and its main core, in the form of a synthesis strategic plan and market competition, is to find the optimal combination of vectors of rationality and efficiency when implemented and all major changes in the socioeconomic relations and, above all, in the regulation of the national macroeconomic environment.

The search for an optimal combination of vectors of rationality and efficiency in the implementation of all large-scale transformations in the macroeconomic environment occurs on the intuitive-empirical level of representations, trial method, error, and the principle of a pendulum when the preference is given to rationality or efficiency, or vice versa.

The multi-vector relationship of rationalization and efficiency in the regulatory system allows us to conclude that the nature of the modern industrial development potential under conditions of rapid and rapid change, contradictory and unpredictable processes, international integration and globalization, increased competition provides a refusal to seek and use a universal, single means or formulas for regulating the development of industry and its structural units in the national macroeconomic environment.

Therefore, it is necessary to combine not only different but also mutually exclusive positions to carry out a balanced combination of components of the process of regulating the development of industry, based on adequate requirements of reality and long-term strategic efficiency of the functioning of the subjects of the national economy. The strategic opportunity of such a productive combination is contained in all the real options or alternatives to the development of industry, provided the optimal basis of the combination is found.

Alternative development options in the industrial sector:

- internationalization with the use of insuring, which provides self-sufficiency of internal resources of the industrial industry and the extermination as a pool of competences of the subjects of the macroeconomic environment within the relationship of partnership and interdependence;

- centralization and decentralization of controlled segments of the industrial sector;

- development of associative intra-industry and interbranch associations;

- the nature and extent of institutional intervention in the formation, operation, and development of the industrial sector and its structural units; 
- application of the system integrator of industrial infrastructure development;

- the optimal ratio of innovation-investment approach in the development of the industrial sector.

The development of industry in the national macroeconomic environment should deviate from the raw material-oriented model, and be guided by the model of maximum value added.

The results of management in the industry are characterized by the following instrumental provision: added value, profitability and sectoral cumulative income, which determine and confirm the competitiveness of the industry and its subjects, their potential development and business activity.

Analytical information on the formation of a net financial result in the industry for five years is presented in Table 3.

The trend in recent years has shown the resumption of positive results in the industrial sector. With an increase in the net income from the sale of industrial products in 2.87 times in 2017 in relation to 2013, the net financial result increased 14.47 times.

The financial and economic outcomes of the industry in the country are far from indifferent to the relevant institutions of the national macroeconomic environment in terms of the ability of its subjects to pay in full their obligations on taxes and fees.

In turn, the share of subjects of the industrial sector, which received losses is constantly decreasing, and profit - is increasing, which indicates the dynamic growth of economic performance in the industry and the potential for its effective development.

The main analytical tool that shows the effectiveness of business results in the industrial sector is profitability.
The profitability of operating activities in the industry by type of economic activity for 2013-2018 is presented in Table 4.

The total profitability of the main activities of the industrial sector shows the positive dynamics of the last five years, indicating a gradual recovery of the potential for its development. Profitability from 1.6\% (2013) to $7.0 \%(2018)$ is a confirmation. An increase in profitability, with a negative net financial result in 2014-2016, shows a significant impact on the results of management in the industrial sector of income and expenditure from the investment and financial activities of its subjects.

The profitability of the industry is its profitability and the tool for evaluating the economic efficiency of the activity. Analytical indicator of profitability comprehensively reflects the degree of efficiency of using financial, material and labour resources in the industry.

Indicators of profitability of operational activity in the industry by types of industrial activity indicate the diverse efficiency of their work. The highest profitability is observed in the extractive industry and the development of quarries $(40.9 \%)$, while the lowest, negative - water supply, sewage, waste management $(-5.9 \%)$.

Dynamic analysis of sources and structure of financing of innovative activity of the industrial sector of the national economy of Ukraine for the period of 2000-2018 reflects the minimum share of the state in its financing.

It should also be noted that the innovation and investment capacity in the industry is primarily due to the financial potential of its subjects, which is noticeably increasing, the evidence of which in recent years is the dynamics of capital investment in industry (Figure 2).

Table 3

Formation of net financial result in the industry (UAH million)

\begin{tabular}{|l|c|c|c|c|c|}
\hline \multicolumn{1}{|c|}{ Indexes } & \multicolumn{4}{c|}{ Years } \\
\cline { 2 - 6 } & 2013 & 2014 & 2015 & 2016 & 2017 \\
\hline $\begin{array}{l}\text { Net income from sales and net earned } \\
\text { insurance premiums }\end{array}$ & 962468,6 & 1488759,1 & 1854656,7 & 2249905,6 & 2760386,3 \\
\hline Other operating income & 104483,4 & 193102,8 & 280319,6 & 180307,0 & 156979,2 \\
\hline Other income & 16983,0 & 50131,5 & 135957,8 & 106274,6 & 61777,9 \\
\hline Operating expenses & 1033853,9 & 1655055,5 & 2116227,4 & 2332869,4 & 2730516,9 \\
\hline Other expenses & 38768,3 & 243351,8 & 336067,5 & 211187,3 & 161164,8 \\
\hline Cost of sold products (goods, works, services) & 943865,7 & 1243362,8 & 1544980,2 & 1881663,1 & 2273216,3 \\
\hline Net financial result & 3670,6 & $-178730,9$ & $-188267,9$ & $-24724,7$ & 56124,0 \\
\hline
\end{tabular}

Table 4

Cost-effectiveness of operating activities in the industry (\%)

\begin{tabular}{|l|c|c|c|c|c|c|}
\hline \multirow{2}{*}{\multicolumn{1}{c|}{ Industrial sector }} & \multicolumn{3}{c|}{ Years } \\
\cline { 2 - 8 } & 2013 & 2014 & 2015 & 2016 & 2017 & $2018^{*}$ \\
\hline Industry & $-3,0$ & 1,6 & 0,9 & 4,2 & 6,8 & 7,0 \\
\hline Mining and quarrying & 12,5 & 21,4 & 6,4 & 16,7 & 34 & 40,9 \\
\hline Manufacturing industry & 2,1 & $-0,6$ & 0,7 & 3,0 & 4,6 & 3,4 \\
\hline Supply of electricity, gas, steam and air conditioning & 1,3 & $-0,1$ & $-0,8$ & 2,1 & 1,5 & 2,4 \\
\hline Water supply; sewage, waste management & $-6,6$ & $-4,9$ & $-5,7$ & $-8,0$ & $-3,0$ & $-5,9$ \\
\hline
\end{tabular}




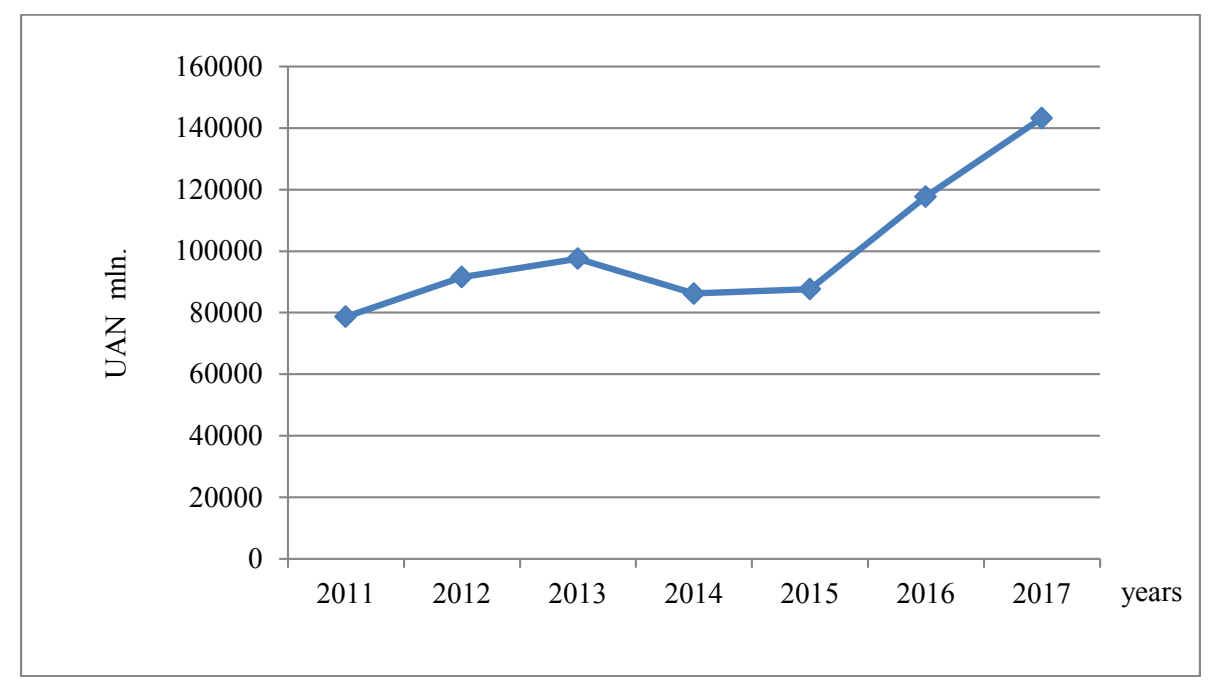

Figure 2. Dynamics of capital investments in industry for the period of 2011-2017 (UAH million) (built on the data of the State Statistics Service of Ukraine)

The main factors that in recent times have a significant impact on industrial development: political instability, partial annexation of the country's territory, sectoral problems in the national macroeconomic environment, and others.

The main problem areas of regulation development of industry in the national macroeconomic environment should include the following:

- political instability and hostilities in the eastern part of the country;

- absence of a single innovation-investment development strategy in the national macroeconomic environment;

- a significant outflow of skilled labour necessary for the development of the industry;

- high dependence on the export of raw materials;

- prevalence of subjects of the industry with low added value;

- a significant level of import of industrial products;

- disproportionate regional concentration of subjects and objects of the industrial sector;

- insufficient resource efficiency in the industrial sector;

- not systematic environmental measures and a high level of pollution;

- lack of synchronization of all processes in the national macroeconomic environment, taking into account the vectorial orientation of the country's development.

The analysis of the goals of national development and the expected contribution of industrial policy to their achievement, as well as the search for ways to solve the key problems of industrial development, has allowed to distinguish the following tasks of the Industrial Development Strategies, which can be defined as intersectoral priorities of the industrial policy of the country in the medium-term perspective: modernization and growth of industrial production; regional development of industry; increase of resource efficiency of industry (Strategy of development of the industrial complex of Ukraine for the period till 2025, 2018).

\section{Conclusions}

The main functions of regulating the development of the industrial sector are: comprehensive support and development of competition in the industrial market; adequate antimonopoly regulation; protection of the rights of industry and consumers of their products; support for the effective functioning of the subjects of the industrial industry and their structural units.

The conceptual guidelines for the regulation of industrial development should include the following: the study of the existing components of the industrial development environment in the national economy; identification and isolation of weaknesses in the components of the institutional regulatory environment that influence the effectiveness of socio-economic development of the subjects of the industrial sector; the formation of systemic measures to create favourable conditions for the development of industry in the national macroeconomic environment; development of intra-industry and inter-sectoral regional and national programs to promote the effective development of industry; calculation of expenses for the implementation of the proposed program and its expected efficiency; formation of alternative development programs.

Effective regulation of the development of industry in the national economy is to create a favourable institutional environment for qualitative development in accordance with the stated goal, strategic goals and tasks at the national and regional level. Thus, the main goal of regulating the development of industry in the national economy is to adhere to the priority line of growth of positive results of industrial activities that will ensure socio-economic development of the sector and macroeconomic indicators of the country.

The application of certain forms of regulation of the development of industry in the national economy depends on the conditions of the functioning of the 
national macroeconomic environment, the set strategic goals, and the international situation. The rationality and efficiency of the industrial development regulation system can have both the same and opposite vectors of direction relative to the total component of these vectors of the effectiveness of the regulatory system in the national macroeconomic environment.

The process of regulating the development of industry in the national economy operates primarily as an ordered system; therefore, it is expedient to consider the regulation of industrial development in terms of a systemic approach in the macroeconomic environment. The basic elements of a particular system are the purpose, strategic objectives and objectives, principles and constraints, regulatory functions, as well as institutional actors that have an impact on industry and its structural units, with the help of wellgrounded tools, taking into account relevant factors and guided by the corresponding result of the national development of the country: sustainable economic development in the national space; social stability and a rise in living standards in a national society; ensuring an adequate level of national security. As a result, the industrial sector should become the main driver of innovation and investment development in the national macroeconomic environment of the country.

\section{References:}

Concept of the national target economic program of development of industry for the period up to 2020: Order of the Cabinet of Ministers of Ukraine dated July 17, 2013, No. 603-p. Date updated: 12/25/2013. Retrieved from: https://zakon.rada.gov.ua/laws/show/603-2013-\%D1\%80 (accessed 12 June 2019).

Melnik, A. F., Vasina, A. Yu., Zhyluk, T. L., Popovich, T. M. (2011). National economy: teaching. manual / ed. A. F. Miller. Kyiv: Knowledge. Retrieved from: https://idruchniki.com/1212012441817/economics/ derzhavne_regulyuvannya (accessed 12 June 2019).

Official website of the State Statistics Service of Ukraine. Retrieved from: http:/ /ukrstat.gov.ua (accessed 12 June 2019). Strategy for the development of the industrial complex of Ukraine for the period up to 2025. Project. Official text dated April 17, 2014. Retrieved from: http://search.ligazakon.ua/1_doc2.nsf/link1/NT4284.html (accessed 12 June 2019).

Stigler George, J. (1971). The theory of economic regulation. The Bell Journal of Economics and Management Science, 2(1), 3-21.

Trebing Harry, M. (1987). Regulation of industry: an institutionalist approach. Journal of Economic Issues, 21, 1707-1737.

Vengega, D. I. (2015). Strategic directions of increasing the efficiency of state regulation of industrial production in Ukraine. Global and national problems of the economy, 6, 112-118. Retrieved from: http://global-national.in.ua/ archive/6-2015/24.pdf (accessed 12 June 2019). 